\title{
Bovine And Human Zona Pellucida 3 Gene Glycans Site Prediction Using In Silico Analysis
}

\author{
Nurul Jadid Mubarakati ${ }^{1}$, Aulanni'am Aulanni'am ${ }^{2,3^{*}}$, Sutiman Bambang Sumitro ${ }^{4}$, Gatot Ciptadi $^{5}$ \\ ${ }^{1}$ Faculty of Mathematics And Natural Sciences, Biology Department, University of Islamic Malang, Indonesia \\ ${ }^{2}$ School of Veterinary Medicine, University of Brawijaya, Indonesia \\ ${ }^{3}$ Biochemistry Laboratory, Chemistry Department, University of Brawijaya, Indonesia \\ ${ }^{4}$ Laboratory of Cellular and Molecular Biology, University of Brawijaya, Indonesia \\ ${ }^{5}$ Faculty of Animal Husbandry, University of Brawijaya, Indonesia
}

\begin{abstract}
Zona pellucida is one of the protective layer of the egg cell and has a function as an intermediary speciesspecific fertilization. Glycoproteins of human and bovine zona pellucida is composed of three types, namely ZP1, ZP2 and ZP3. ZP3 gene has amino acid sequence homology with other mammals. Oligosaccharides components of the zona pellucida glycans are composed from units of asparagine residues $(\mathrm{N}$-linked) and serine/threonine $(\mathrm{O}$ -linked). The aims of this study was to analyze the DNA sequences of human and bovine and further predicts glycans site on amino acid sequence of human and bovine ZP3. In this study, ZP3 gene fragments have been isolated from bovine and humans were analyzed in Silico. This work were conducted by comparing the data of DNA sequence from human and bovine PCR product using NCBI BLAST. The results showed that there were similarities at amino acid positions number 23-38. bZP3 sequence had three glycans site (Asn-X-Thr/Ser) and one site on hZP3 glycans. One of the sites was conserved between the two species.
\end{abstract}

Keywords: fertilization, glycan site, human and bovine zona pellucida 3, in silico analysis, ZP3 protein structure

\section{INTRODUCTION}

Fertilization is the process of a sperm joining an egg that involves cell-cell fusion of sperm with oocyte. Important aspect of early development that understanding of the mechanisms these interaction events and study cellular function [1]. This interaction between highly specialised cells provides a unique example of many cellular processes which is initiated by specific cell adhession, cell signaling, regulated exocytosis, cell migration, cell fussion, regulation of cell cycles and finally the initiation of embryonic development [1].

Galactosyltransferase is a protein in the sperm surface to specific glycoside ligand on the egg that may act as the receptor that binds to the zona pellucida 3 and initiates the acrosome reaction [2]. The enzyme Beta1,4-galactosyl-transferase I (GalTase) was one of the first mole-cules involved in sperm-egg interaction which was studied [3]. If there are blockade in the ZP3

\footnotetext{
${ }^{*}$ Corresponding author:

Aulanni'am Aulanni'am

School of Veterinary Medicine, University of Brawijaya

Indonesia

E-mail: aulanibiochems@gmail.com
}

sperm interaction fertilization will not occur. This is the basis for developing alternative vac-cine immunocontraception methods aimed to blocking fertilization by way of immune response mechanisms induction that interfere with recep-tor-ligand binding exist in the egg and sperm [4].

Information about the primary structure and function of the zona pellucida proteins from other species, especially cattle and humans is very little. Zona pellucida in humans and cows iscomposed of three glycoproteins ZP1, ZP2 and ZP3, each of which has a function in the fertilization process. In this study showed that zona pellucida protein 3 coding gene have in common with other mammals.

Biocomputation technological developments become an alternative to identify and predict the structure of a gene or protein function based on existing information. The protein structure and function are able to predicted and reconstructed based on known DNA sequence, therefore this research will be the structure reconstruction of the zona pellucida protein 3 so the glycan sites of bovine and human ZP3 are able to predicted. 


\section{MATERIALS AND METHODS}

\section{Isolation of $b Z P 3 D N A$}

bZP3 DNA from oocyte colection were washed with PBS and centrifuged $11.000 \mathrm{rpm}$ for $15 \mathrm{~min}$. Buffer lysis and proteinase $\mathrm{K}$ were added and homogened. Oocyte incubated one until three hour at $56^{\circ} \mathrm{C}$. Buffer lysis added and incubation at $70^{\circ} \mathrm{C}$ in 10 min, homogene and ethanol absolute were added. Oocyte homogenate were transfered to membrane silica in a tube and washed with buffer and then sentrifuged $11.000 \mathrm{rpm}$, one minute. Supernatant were removed and the pellet were resuspended with TE buffer. bZP3 DNA concentration were measured using UV-Vis spectrophotometer.

\section{Human Blood DNA Isolation}

Blood from EDTA tube transfered to propilen tube and added RBC lysis. Incubated in temperature room for $10 \mathrm{~min}$ and centrifuged in $3000 \mathrm{rpm}$ for $10 \mathrm{~min}$ at $25^{\circ} \mathrm{C}$. Pellet added with cell lysis solution, mix gentle, incubated at $37^{\circ} \mathrm{C}$ shaker waterbath. $\mathrm{EtOH}$ absolut were added and centrifugated in $10.000 \mathrm{rpm}$ and the pellet were mixed with $70 \%$ ethanol. After that, the pellet were dried out and added with TE buffer $\mathrm{pH} 7,6$ and stored in $-20^{\circ} \mathrm{C}$. The human sera used in the reaserch was approved by ethics committee Faculty of Medicine, Brawijaya University. $94^{\circ} \mathrm{C}$ for $1 \mathrm{~min}, 40$ cycles at $94^{\circ} \mathrm{C}$ for 30 second, 57 ${ }^{\circ} \mathrm{C}$ for 30 second, $72^{\circ} \mathrm{C}$ for 45 second, and the final extension at $72^{\circ} \mathrm{C}$ for $7 \mathrm{~min}$. Oligonucleotide primers $\left(5^{\prime}\right.$ to $\left.3^{\prime}\right)$ hybridizing to the coding strand include: reverse 5’ATGC CTC GAG CTA CCT GCG GTT ACG GGA AGC-3' and forward 5'ATGC GGA TCC ATG GTG GAA GGC TCG GCT GAC-3' by $10 \mathrm{pmol} / \mu \mathrm{l}$ concentration, incorporating $\mathrm{BamH1}$ and Xho1 restriction sites, respectively. The PCR products were electrophoresed on $1,5 \%$ agarose gels.

\section{In Silico Analysis}

PCR products were purified first and DNA sequences were confirmed by DNA sequencing using an ABI Prism 3100 sequencer-avant genetic analyzer (4 capillaries) products from Applied Biosystems USA. The method used was fluo-rescent-dye terminator cycle sequencing. Analysis of alignment DNA sequences hZP3 and bZP3 used BLAST program found on the NCBI.

\section{RESULTS AND DISCUSSION}

Whole DNA from human and bovine were electrophoresed on 1,5\% agarose gels. Concentration of whole DNA from human was $59,4 \mu \mathrm{g} / \mathrm{ml}$ (line 3) and bovine was $26,9 \mu \mathrm{g} / \mathrm{ml}$ (line 1-2) (figure $1 \mathrm{~A}$ ).

$\mathrm{ZP} 3$ gene fragments from human and bovine prod

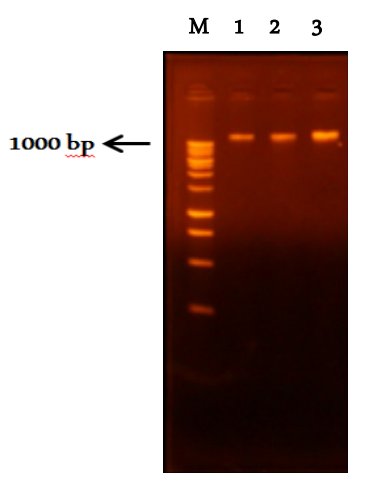

A

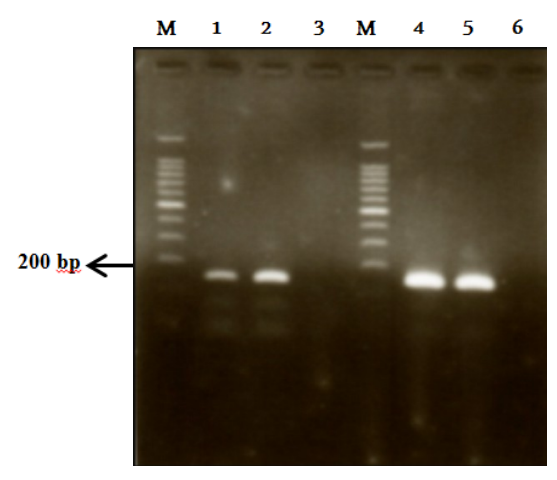

B

Figure 1. A. Electroforeted product of whole DNA human and bovine in agarose gel 1,5\% with ethidium bromide. Band of whole DNA have more than 10000 base pair. M : DNA ladder 10000 bp; line 1-2 : oocyte from bovine; line 3: human blood. DNA documented using gel documentation system. B. PCR product was electroforeted showed Zona pellucida 3 gen from human and bovine in agarose gel 1,5\%. M : DNA ladder 100 bp; lane 1-2 :hZP3; lane 4-5: bZP3; lane 3 and 6 : negative control.

\section{DNA Target Amplification}

Isolated DNA from human blood were used as a template for first-strand synthesis with oligonucleotide primer. The first strand was amplified by PCR. PCRamplification cycles involved: initial denaturation at uct PCR showed a band of $\sim 200 \mathrm{bp}$, then nucleotide sequence were determine using fluorescent-dye terminator cycle sequencing (figure 1B). 


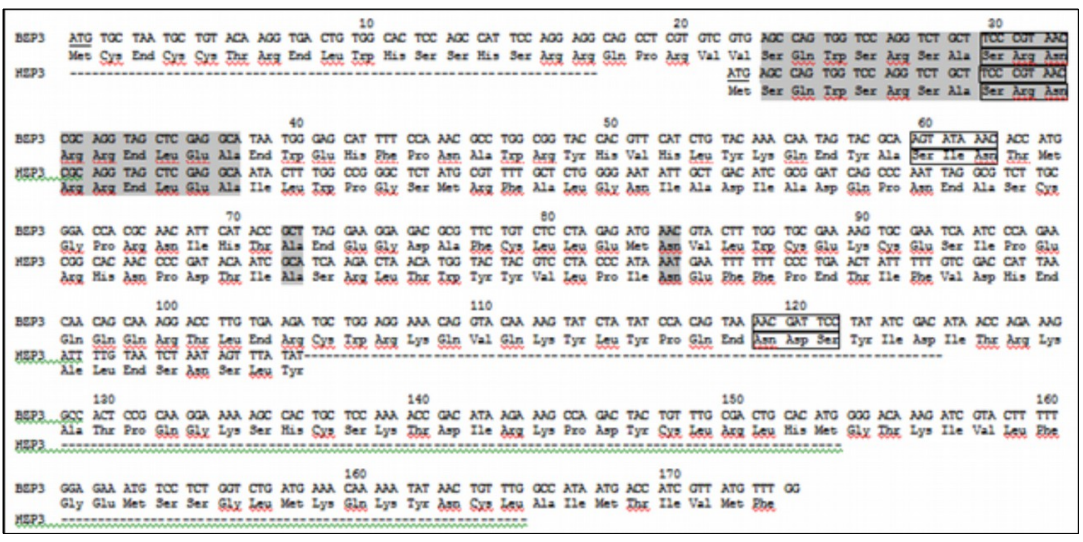

Figure 2. Sequence DNA-amino acid between human ZP3 and bovine ZP3

Sequence of ZP3 gene that isolated from human and bovine showed similarity in amino acid (figure 2). The percentage of amino acid similarity between mice with hamster $83.5 \%$, 95.5\% human with monkeys, cows with pigs $84.3 \%$ and $73.1 \%$ of cows with human [5].

Amino acid sequence of human and bovine had similarities positions include SQWSRSASRNRR at position 23-38. These sequence showed homology with several published sequences, several of them have been shown to be expressed in ZP3 of the oocyte. Allignment analysis using NCBI BLAST showed homology among various species mammalia in this region of the $\mathrm{ZP} 3$ protein. This region might contribute towards the species-specificity of sperm-egg binding.

In humans, $\mathrm{ZP} 3$ identified as a primary receptor sites for spermatozoa and highly glycosylated containing N-Linked and O-linked glycan units. These proteins are suffiently conserved between mammalian species. ZP3 bound to acrosome intact sperm [6]. Oligo-saccharides are found on all three glycoproteins on both asparagine (N-linked) and Serin/ Threonin (O-Linked) residues which is improved as mediators of sperm-egg recognition, attach-ment and binding, and acrosomal exocytosis [7]. In our analysis, bZP3 sequence had three glycans site (Asn-X-Thr/Ser) and one site on hZP3 glycans. One of the sites was conserved between the two species.

\section{CONCLUSIONS}

There were similarities between the amino acid sequences of human and bovine were the amino acid positions on 23-38. bZP3 sequence had three glycans site (Asn-X-Thr/Ser) and one site on hZP3 glycans. One of the sites was conserved between the two species.
Amino acid region SQWSRSASRNRR were homology among various species mammalia.

\section{ACKNOWLEDGEMENT}

Authors would like to thank Prof. Wolfgang Nellen, Kassel University, Germany for providing pET28 and E. coli BL21 competent cells.

\section{REFERENCES}

1. Florman HM, Ducibella T (2006) Fertilization in Mammals. Knobil and Neill's Physiology of Reproduction, Third Edition, edited by Jimmy D. Neill. Elsevier. Pp 5556.

2. Shur BD, Rodeheffer C, Ensslin MA, Lyng R, Raymond A (2006) Identification Of Novel Gamete Receptors That Mediate Sperm Adhesion To The Egg Coat. Molecular and Cellular Endocrinology. 250: 137-148.

3. Mugnier S, Boittin S, Douet C, Monget P, Magistrini M, Goudet G (2008) The involvement of beta-1,4-galactosyltransferase and $\mathrm{N}$-acetylglucosamine residues in fertilization has been lost in the horse. Reproductive Biology and Endocrinology. 6: 51.

4. Sumitro SB, Aulanni'am (2001) Zona pellucida 3 (ZP3) Has Proper Biochemical Properties To Be Considered As Candidate Antigen For Immunoontraceptive Vaccine. Reprotech. 1: 51-53.

5. Zhu X, Naz RK (1999) Comparison of ZP3 Protein Sequences Among Vertebrate Species: To Obtain A Consensus Sequence For Immunocontraception. Frontiers in Bioscience. 4: 212-215.

6. Dean J (2006) The enigma of sperm-egg recognition in mice. In: Gupta SK, Koyama K, Murray FF (Eds.), Gamete Biology: Emerging Frontiers in Fertility and Contraceptive Development. Nottingham University Press. Nottingham. Pp 359-365.

7. Gupta SK, Chakravarty S, Suraj K, Bansal P, Ganguly A, 
Jain MK, Bhandari B (2006) Structural and functional attributes of zona pellucida glycoproteins. In: Gupta, S.K., Koyama, K., Murray, F.F. (Eds.), Gamete Biology: Emerg- ing Frontiers in Fertility and Contraceptive Development. Nottingham University Press. Nottingham. Pp 203-216. 